\title{
Guar Korma: A Good Alternate to Replace Groundnut Cake in the Diet of Buffalo Calves: A Review
}

\author{
Mohit Antil ${ }^{1 *}$ and Sandeep Chhikara ${ }^{2}$ \\ ${ }^{1}$ Micro Credit Innovation Department, National Bank of Agriculture and Rural Development, \\ Rajasthan Regional Office, Jaipur, India \\ ${ }^{2}$ Department of Animal Husbandry and Dairying, Haryana, India \\ *Corresponding author
}

\section{A B S T R A C T}

\begin{tabular}{|c|}
\hline Keywords \\
\hline $\begin{array}{l}\text { Guar Korma, } \\
\text { Groundnut Cake, } \\
\text { Diet of Buffalo } \\
\text { Calves }\end{array}$ \\
\hline Article Info \\
\hline $\begin{array}{l}\text { Accepted: } \\
\text { 15 January } 2019 \\
\text { Available Online: } \\
10 \text { February } 2019\end{array}$ \\
\hline
\end{tabular}

\section{Introduction}

\section{Guar (Cyamposis tetragonoloba)}

Guar, commonly known as cluster bean, is a drought and high temperature tolerant deep rooted summer annual legume of high social and economic significance (Mishra et al., 2013).

The qualities of the crop like high adaptation towards erratic rainfall, multiple industrial uses and its importance in cropping system for factors such as soil enrichment properties, low input requirement, etc. have made the guar one of the most significant crops for farmers in arid areas in India.

Guar is a native to the Indian subcontinent. The crop is mainly grown in the dry habitats of Rajasthan, Haryana, Gujarat and Punjab and to limited extent in Uttar Pradesh and Madhya Pradesh. The crop is also grown in other parts of the world, like Australia, Brazil and South Africa. India is the largest producer of guar and contributes 80 percent of total guar production in the world (APEDA, 2011). In India, guar crop is cultivated mainly during 
Kharif season. Like other legumes, guar is an excellent soil-building crop with respect to availability of nitrogen. Root nodules contain nitrogen-fixing bacteria and crop residues, when ploughed under, improves yields of succeeding crops.

\section{Uses of guar}

Guar crop has experienced a remarkable journey from a traditional crop grown on marginal lands mainly for food, animal feed and fodder to a crop with various industrial usages. Guar gum is an important ingredient in producing food emulsifier, food additive, food thickener and other guar gum products (Vishwakarma et al., 2012). The unique binding, thickening and emulsifying quality of guar gum powder obtained from guar seed has made it a much sought after product in international market. Guar is the source of a natural hydrocolloid, which is cold water soluble and form thick solution at low concentrations (Sharma and Gummagolmath, 2012).

\section{Processing of guar seed}

The guar seed consists of three parts: the seed coat (14-17\%), the endosperm (35-42\%) and the germ (43-47\%) (Lee et al., 2004). The seeds are broken and the germ is separated from the endosperm. Two halves of the endosperm are obtained from each seed and are known as undehusked guar split. When the fine layer of fibrous material, which forms the husk, is removed and separated from the endosperm halves by polishing, refined guar splits are obtained. The refined guar splits are then treated and finished into powders known as guar gum, by a variety of routes and processing techniques depending upon the end product desired. The hull (husk) and germ portion of guar seed are termed as guar meal. Guar meal typically comes in two forms i.e. guar meal churi, which is a powder and guar korma meal, which is a granular form. Extracts from guar seed include guar split/gum (29\%), korma (30-35\%) and churi $(35-40 \%)$ (APEDA, 2011).

\section{Chemical composition of roasted guar korma}

Tyagi et al., (2011) reported that roasted guar korma contained $50.27 \%$ protein, $5.32 \%$ ether extract, $6.24 \%$ crude fiber, $7.08 \%$ total ash, $1.28 \%$ acid insoluble ash, $31.09 \%$ NFE, $0.13 \%$ calcium and $0.30 \%$ phosphorus on dry matter basis. Grewal et al., (2014) suggested that roasted guar korma has 95.1\% OM, $46.9 \% \mathrm{CP}, 4.9 \%$ ASH, 31.6\% NDF, $8.7 \%$ $\mathrm{ADF}, 6.6 \% \mathrm{EE}$ and $11.9 \mathrm{MJ} / \mathrm{kg}$ of $\mathrm{ME}$.

Nidhina and Muthukumar (2015) reported the chemical composition of guar korma as moisture $8.2 \%$, Ash $5.1 \%$, crude fiber $4.9 \%$, protein $52.7 \%$, NFE $23.6 \%$ and ether extract $5.4 \%$

Walaa et al., (2016) founded that guar korma meal contained $50.00 \% \mathrm{CP}, 10.80 \% \mathrm{CF}$, $2.86 \%$ EE, $4.15 \%$ TA and $32.19 \%$ NFE whereas, similar values reported by Soliman et al., (2014) were 55.80\%, 7.50\%, 4.70\%, $5.40 \%$ and $26.00 \%$; by Saeed et al., (2017) were $56-58 \%, 3-4 \%, 4-5 \%, 1-2 \%$ and $21-25 \%$ and by Etman et al., (2014) were $50.00 \%$, $6.70 \%, 6.00 \%, \quad 5.00 \%$ and $32.30 \%$, respectively.

\section{Antinutritional factors}

Couch et al., (1967) reported that trypsin inhibitor and residual gum are the two detrimental factors present in guar meal. Subramanian and Parpia (1975) reported that guar meal contains toxic factors such as trypsin inhibitor, haemagglutinin, extractable polyphenols and saponins. Guar meal contains about $12 \%$ gum residue $(7 \%$ in the germ fraction and $13 \%$ in the hulls), which 
increases viscosity in the intestine, resulting in lower digestibility and growth performance (Lee et al., 2009).

Anti-trypsin activity was found to be lower in heat-treated guar meal and therefore not the main cause of antinutritional effects in poultry (Lee et al., 2004).Other types of antinutritional factors presents are trypsin inhibitors, saponin, haemagglutinins, hydrocyanic acid and polyphenols (Verma et al.,1982; Gutierrez et al., 2007). Hassan et al., (2013) conducted a study in one day old broiler chicks and concluded that guar gum is the primary anti nutritional factor in guar meal. The large saponin content of guar seed (up to $13 \% \mathrm{DM}$ ) could have both antinutritional effect and a positive antimicrobial activity (Hassan et al., 2010).

In another study by Hassan et al., (2013) to evaluate whether saponin rich guar meal extract or residual guar gum is the main antinutritional compound contributing to guar meal, chicks were fed one of four treatments: control broiler diet, control diet containing $5.00 \%$ guar meal, control diet containing $0.90 \%$ guar gum and control diet containing $0.25 \%$ guar saponin.

Productive performance of broiler chicks in the present study was less negatively inhibited by $0.90 \%$ guar gum treatment suggesting that triterpenoid saponins may be the most important anti-nutritional factor. Nidhina and Muthukumar (2015) reported that guar korma meal has $8.20+0.09 \mathrm{mg} / \mathrm{g}$ trypsin inhibitor activity, $29.80 \pm 0.60 \mathrm{mg} / \mathrm{g}$ phytate, $5.90 \pm 0.20$ $\mathrm{mg} / \mathrm{g}$ tannin and $27.50 \pm 1.90 \mathrm{mg} / \mathrm{g}$ saponin.

\section{Processing of guar meal to reduce anti- nutritional factors}

Couch et al., (1967) suggested that trypsin inhibitor can be destroyed by cooking the raw guar meal for a period of $1 \mathrm{hr}$ at a temperature of $110^{\circ} \mathrm{C}$ with the injection of superheated steam for a period of $15 \mathrm{~min}$ after the cooker attains a temperature of $110^{\circ} \mathrm{C}$.

Processing (toasting) by subjecting guar meal to steam and dry heat removes beany odour and gum residue, including the adhesive characteristics Rahman and Leighton (1968). Tasneem and Subramanian (1990) suggested that diluted acid extraction, autoclaving or aqueous alcohol of guar meal improves the nutritive value. Autoclaving guar meal can destroy the haemagglutinins (84\%), trypsin inhibitors (84\%), saponin $(6.1 \%)$ and phytate (7.5\%) (Rajput et al., 1998). In a study by Mishra et al., (2013) supplementation of $\beta$ mannase was not found worthwhile in alleviating the negative effects of guar korma. Nidhina and Muthukumar (2015) concluded that autoclaving the guar meal at $121^{\circ} \mathrm{C}$ for 15 min. reduced trypsin inhibitor by $66.7 \%$ and eliminated $85 \%$ phytic acid. Boiling was effective in reducing $64.5 \%$ of tannin content. Soaking of dehulled guar meal increased the protein content of guar meal up to $67.8 \%$ from $52.6 \%$ (Ahmed et al., 2006).

Sadagopan and Talapatra (1968) reported that guar meal as a part of balanced ration did not result in any digestive disorder. But when fed as a sole concentrate to the growing calves it resulted in chronic diarrhoea. Experiments were conducted to detoxify the guar meal by using different methods of processing. The treatments given to guar meal were:

a) Extraction with boiling water

b) Treatment with $1 \mathrm{~N} \mathrm{HCl}$

The utilization of treated and untreated guar meal was determined by feeding these meals to rats at $10 \%$ protein level and using casein as control. It was seen that there was considerable improvement in growth in both hot water and $\mathrm{HCl}$ treated guar meal (Kawatra et al., 1969). 
The effect of replacement of groundnut cake with guar korma on growth performance in buffalo calves

\section{Weight gain in growing calves}

There was non-significant $(\mathrm{P}>0.05)$ effect of replacing cotton seed cake with guar meal on weight gain in Sahiwal calves. The average daily gain was $622.78 \mathrm{~g} /$ day for calves fed cotton seed cake based diet and 610.22 and $615.89 \mathrm{~g} / \mathrm{d}$ for calves fed guar meal and $\mathrm{CSC}+\mathrm{GM}$ based diets, respectively (Sharif $e t$ al., 2014).

Etman et al., (2014a) conducted trial on growing male buffalo calves and replaced concentrate mixture protein (ration A) to $10 \%$ (ration B), 20\% (ration C), 30\% (ration D), $40 \%$ (ration $\mathrm{E}$ ) and $50 \%$ (ration $\mathrm{F}$ ) by guar korma protein. Averages total live body weight gains were 272.2, 278.3, 284.9, 292.3, 299.2 and $309.8 \mathrm{~kg}$ for animals fed rations $\mathrm{A}$, B, C, D, E and F, respectively. Corresponding, values of daily gains were $1.296,1.325,1.357,1.392,1.425$ and 1.475 $\mathrm{kg} /$ day, respectively in 210 days. It could be noticed that both total and daily gains increased with increasing guar korma levels in experimental rations. The improvements in daily gains were $2.24,4.71,7.41,9.95$ and $13.81 \%$ with animals fed rations B, C, D, E and F, respectively. Sadagopan and Talpatra (1967) carried out investigation to replace the high protein groundnut cake by guar meal at $20 \%$ level in growth ration of Hariana heifers. The average growth rates during the 150 days period were $1.12 \mathrm{lb}$ and $1.11 \mathrm{lb}$ per head per day in GNC group and guar meal group, respectively. The digestibility coefficient of various nutrients in the two groups did not differ significantly. Thus from the studies it was concluded that guar meal appears to replace GNC quite successfully in growth of Hariana calves. Sagar and Pradhan (1975) fed guar meal as a sole protein source in growth ration of crossbred calves. Calves in one group were fed control ration (GML-0) which had groundnut cake while those in second group received experimental ration (GML100 ) in which guar meal was sole protein source. The daily average feed consumption of GML-0 and GML-100 rations were 4.6 and $4.2 \mathrm{~kg}$, respectively. The calves on GML-0 ration ate more than their counterparts, maintained on GML-100 ration. Average daily gains were 640 and $655 \mathrm{~g}$ in control and experimental group, respectively. Heart girth and body length showed a slightly higher gain in calves on GML-100 ration while height and width gain were slightly more in calves in guar free rations. However, these differences were not statistically significant.

Twenty four crossbred calves aged 320 to 390 days were fed on a mixture (2:5) of chaffed wheat straw and mixture containing $72 \%$ maize, $37 \%$ groundnut cake and 1 part mineral mixture. When groundnut cake was replaced by guar meal at 0, 50, and 100\% levels, average daily feed intake was 12.23 , 12.34 , and $11.70 \mathrm{~kg} / 100 \mathrm{~kg}$ metabolic weight. Daily gains were $0.96,1.09$, and 1.07 $\mathrm{kg}$. Feed efficiency was $0.10,0.17$ and $0.17 \%$ and digestibility of DM was 59.6, 63.7 and $66.6 \%$, respectively. Increase in heart girth, height and width were greater and body length was shorter for calves given guar meal (Sagar and Pradhan, 1977).

\section{DM intake and palatability of roasted guar korma}

Jongwe et al., (2014) founded that the incorporation of guar meal in the concentrate mixture of lactating Sahiwal cows did not show any effect on the DM intake. Average DM intake in groups T0 (GNC), T1 (75\% replacement of GNC with guar meal) and $\mathrm{T} 2$ (75\% replacement of GNC with guar meal + sweetener $\quad\left(\right.$ Sucram $\left.{ }^{\circledR}\right)+$ flavour (Lactovanilla®)@ 0.025\%) was 7.65, 7.51 
and $7.59 \mathrm{~kg} / \mathrm{d}$, respectively indicating that the palatability of diet was not adversely affected by guar meal even at $75 \%$ replacement of GNC in the concentrate mixture. El-Monayer et al., (2015) conducted trial on lactating buffaloes and replaced concentrate mixture (CSC and soyabean meal) protein (ration A) to $10 \%$ (ration $\mathrm{B}$ ), $20 \%$ (ration $\mathrm{C}$ ), $30 \%$ (ration D), $40 \%$ (ration $\mathrm{E}$ ) and 50\% (ration $\mathrm{F}$ ) by guar korma protein Total DM intake increased with increasing guar korma levels in concentrate mixture, being 10.420, 10.445, $10.500,10.680 .10 .724$ and $10.768 \mathrm{~kg} /$ day for rations $\mathrm{A}, \mathrm{B}, \mathrm{C}, \mathrm{D}, \mathrm{E}$ and $\mathrm{F}$, respectively. Increasing of DM intake might be due to higher palatable guar korma. Soliman et al., (2014) replaced soyabean meal $\left(\mathrm{R}_{1}\right)$ by guar korma meal in the ration of lactating cows at the rate of $33 \%\left(\mathrm{R}_{2}\right), 66 \%\left(\mathrm{R}_{3}\right)$ and $100 \%\left(\mathrm{R}_{4}\right)$ level. Total dry matter intake (DMI) of rations $R_{3}$ and $R_{4}$ was less than the rations $R_{1}$ and $R_{2}$, these differences were statistically significant at $(\mathrm{P}<0.05)$. Similar trend was recorded for the sheep fed CM. This decrease was most likely due to the some of the beans odour and gum residual from guar korma meal.

DM intake was not affected in growing kids (Janampet et al., 2016) and growing Sahiwal heifers (Sharif et al., 2014) by replacing GNC and CSC with guar meal, respectively. Grewal et al., (2014) reported that DM intake was similar when $10 \%$ Soybean meal in concentrate mixture of growing male buffalo calves was replaced with roasted guar korma up to $70 \%$ level. In dairy cows, palatability problems have been reported when more than $5 \%$ guar meal was included in the diet. However, dairy cows and heifers fed rations containing 10-15\% guar meal got acquainted to its odour and taste after a few days. Intake remained lower than with the control diet (cottonseed meal) but dairy performances were not affected. In growing dairy calves, flavoured guar meal and toasted guar meal gave slightly better rates of intake and gain than raw guar meal during the first month (Rahman and Leighton, 1968). Nelson (1965) have reported palatability problems when five per cent or more of guar Meal was used in concentrate rations for lactating dairy cows. Conrad et al., (1967) observed no palatability problems when beef cattle were group-fed 2.3 $\mathrm{kg}$ of guar meal per animal daily, distributed over sorghum silage.

\section{Nutritive value of roasted guar korma}

Digestibility coefficient of DM, CP, EE, CF, NFE and total carbohydrate of the whole ration (wheat straw+ guar meal) in heifers were 51.55, 67.03, 50.35, 66.44, 58.52 and $60.99 \%$, respectively (Srivastva and Singh, 1960). The only reported OM digestibility is $76 \%$ and $71 \%$ for the processed and unprocessed meal, respectively (Islam Shah et al., 1964). Jongwe et al., (2014) conducted a study in Sahiwal cows replacing GNC $\left(\mathrm{T}_{0}\right)$ with guar meal at $75 \%$ level $\left(\mathrm{T}_{1}\right)$ in the concentrate mixture and reported the digestibility coefficients (\%) for DM, OM, $\mathrm{CP}$, EE, NDF, ADF as 60.00 \pm 1.44 , $70.34 \pm 1.20, \quad 67.46 \pm 0.22, \quad 74.35 \pm 0.24$, $57.21 \pm 0.64, \quad 51.97 \pm 1.30 \%$ for $\mathrm{T}_{0}$ and $60.10 \pm 1.40, \quad 71.37 \pm 1.56, \quad 69.42 \pm 0.16$, $72.78 \pm 0.22,6.20 \pm 1.25,49.68 \pm 2.10$ for $\mathrm{T}_{1}$, respectively.

Grewal et al., (2014) reported that when $10 \%$ soybean meal in concentrate mixture of growing male buffalo calves was replaced with roasted guar korma upto $70 \%$ the nutrient digestibility for DM, OM, CP, NDF and $\mathrm{ADF}$ were 74.21, 77.09, 76.38, 72.72 and $65.23 \%$, respectively and there was no difference in the nutrient digestibility of both the groups.

Soliman et al., (2014) replaced soyabean meal $\left(\mathrm{R}_{1}\right)$ by guar korma meal in the ration of sheep at the rate of $33 \%\left(\mathrm{R}_{2}\right), 66 \%\left(\mathrm{R}_{3}\right)$ and $100 \%\left(R_{4}\right)$ level. Animals fed $R_{1}$ and $R_{3}$ 
showed highest $(\mathrm{P}<0.05)$ digestibility values of DM, OM, and CP compared with other rations. The study showed that the $\mathrm{ADF}$ and cellulose increasing linearly with increasing level of guar korma meal in rations, this led to decreasing $\mathrm{CF}$ digestibility for rations containing guar korma than the control ration $(\mathrm{P}<0.05)$. Nutritive value as TDN and DCP increased significantly $(\mathrm{P}<0.05)$ for animals fed Ration 1 and Ration 3. While, animals fed Rations 2, 4 recorded the lowest values $(\mathrm{P}<0.05)$. All animals showed positive nitrogen balance which ranged between 3.47 and $4.25 \mathrm{gm} \mathrm{N} /$ day. Highest values were obtained with sheep fed R1 and R3 however, the lowest were observed with R4 with significant differences $(\mathrm{P}<0.05)$. Mandal et al., (1989) reported that guar meal was a better energy and protein supplement as compared to groundnut cake in growing male buffalo calves.

Walaa et al., (2016) replaced sunflower meal $\left(\mathrm{R}_{1}\right)$ with guar korma meal at the level of $45 \%$ $\left(\mathrm{R}_{2}\right), 60 \%\left(\mathrm{R}_{3}\right)$ and $75 \%\left(\mathrm{R}_{4}\right)$ in lactating buffaloes. They observed linear increase in the digestibility of $\mathrm{OM}, \mathrm{CP}, \mathrm{CF}$ and NFE. TDN, DCP and ME values also followed the similar trend.

Etman et al., (2014) conducted trial on growing male buffalo calves and replaced CSC and soyabean meal protein (ration A) to 10\% (ration $\mathrm{B}$ ), $20 \%$ (ration $\mathrm{C}$ ), 30\% (ration D), $40 \%$ (ration E) and 50\% (ration F) by guar korma protein. Digestibility coefficients of DM was significantly $(\mathrm{P}<0.05)$ higher for ration $\mathrm{F}(85.79 \%)$, while differences in DM digestibility among other rations were not significant. Also, high significant difference was observed for OM digestibility with ration $\mathrm{F}$ being $93.78 \%$, by increasing guar korma percentage to $16.7 \%$ (ration $\mathrm{F}$ ). $\mathrm{CP}$ digestibility, significantly $(\mathrm{P}<0.05)$ increased being $73.20 \%$ versus 65.25, 65.97, 67.18, 67.44 and $69.43 \%$ with rations $\mathrm{A}, \mathrm{B}, \mathrm{C}, \mathrm{D}$ and
E, respectively. Digestibility of $\mathrm{EE}$ significantly $\quad(\mathrm{P}<0.05) \quad$ increased with increasing guar korma percentages, but differences in EE digestibility between rations $\mathrm{E}$ and $\mathrm{F}$ or among $\mathrm{B}, \mathrm{C}$ and $\mathrm{D}$ rations was not statistically significant. Similar trend was observed for CF digestibility, which increased with increasing guar korma per centages. The CF digestibility recorded 58.81, 60.17, 61.21, $62.23,65.34$ and $65.59 \%$ for rations $\mathrm{A}, \mathrm{B}, \mathrm{C}$, $\mathrm{D}, \mathrm{E}$ and $\mathrm{F}$, respectively. Differences in NFE digestibility among different experimental rations were not significant. The TDN was 68.02, 68.87, 69.06, 69.27, 70.78 and 70.82\% for rations A, B, C, D, E and F, respectively. Corresponding values of DCP were 9.60, 9.84, 9.94, 9.98, 10.32 and $10.99 \%$, respectively.

El-Monayer et al., (2015) conducted trial on lactating buffaloes and replaced cotton seed cake and soyabean meal protein (ration A) to $10 \%$ (ration $\mathrm{B}$ ), $20 \%$ (ration $\mathrm{C}$ ), 30\% (ration D), $40 \%$ (ration E) and 50\% (ration F) by guar korma protein. They observed significant $(\mathrm{P}<0.05)$ differences in DM, OM, CP, EE and $\mathrm{CE}$ digestibility among different experimental rations, while differences in NFE digestibility was not significant. Increasing guar korma level tended to significantly $(\mathrm{P}<0.05)$ improve digestibility of most of nutrients especially with ration $\mathrm{F}$ which contained $16.7 \%$ guar korma. The DM digestibility recorded the highest value $(85.20 \%)$ for ration $F$ versus the lowest value $(82.75 \%)$ recorded for ration $\mathrm{A}$.

Difference in DM digestibility among rations $\mathrm{A}, \mathrm{B}, \mathrm{C}$ and $\mathrm{D}$ was non-significant. Ration $\mathrm{F}$ containing the highest level of guar korma $(16.7 \%)$ had the highest feeding values, being $71.03 \% \mathrm{TDN}, 10.15 \% \mathrm{DCP}$ and $3.13 \mathrm{Mcal} / \mathrm{kg}$ DE. Increase in feeding values of experimental rations containing guar korma might be due to their higher nutrient digestibility and increased DM intake. 
Effect of replacement of groundnut cake with guar korma on rumen fermentation pattern in buffaloes

\section{Protein kinetics in rumen}

The degradability of DM and CP plays a vital role in deciding the rumen fermentation pattern of a feedstuff. It can be measured by in vivo methods (Chaturvedi and Walli, 1995) and in-vitro methods (Walli et al., 2000).

In-vitro methods are quicker for screening of large number of feeds but do not give protein degradability in absolute terms. InSacco method is widely accepted to measure the degradability, which is analyzed by a computer model developed by Orskov and McDonald (1979).

But result obtained may differ depending on bag pore size, fineness of grinding, sample size, sample size to bag surface ratio, position of the bag in the rumen, microbial population/ contamination of bag residues and incubation time (Micchalet- Doreau and Bah, 1993; Nocek, 1988 and Stern et al., 1997).

To avoid these problems and maintaining fistulated animals for the in Sacco studies, Sniffen et al., (1992) proposed partitioning of protein by subjecting the feeds to digestion in different solvents/ detergents based on Cornell Net Carbohydrate and Protein (CNCP) model. This system divides feed proteins in five fractions that differ widely in rate of rumen degradation. Estimation of these fractions can help to estimate RDP and RUP values of feedstuffs. Four fractions are estimated chemically (A, $\left.\mathrm{B}_{1}, \mathrm{~B}_{3}, \mathrm{C}\right)$ based on solubility in different solutions and fifth $\left(\mathrm{B}_{2}\right)$ by difference.

$\left(\mathbf{A}+\mathbf{B}_{1}\right):$ Corresponds to non-protein nitrogen and rapidly degradable true proteins (all globulin and some albumin). This fraction is soluble in phosphate buffer.

$\mathbf{B}_{2}$ : (BIN - NDIN) is rest of albumin and all glutelins. This true protein have intermediate degradation rate.

$\mathbf{B}_{3}$ : (NDIN - ADIN) is prolamins, extension proteins and denatured protein, and is slowly degradable.

C: It is derived from acid detergent insoluble nitrogen (ADIN). This fraction corresponds to Maillard products and $\mathrm{N}$ bound to lignin. Undegradable in the rumen and unavailable at intestine.

ADIN: Undegradable in the rumen and unavailable at intestine (heat damaged Maillard products, $\mathrm{N}$ bound to lignin and tannins) Licitra et al., (1996)

BIN: Insoluble $\mathrm{N}$ upon treatment with boratephosphate buffer $(\mathrm{pH}=6.7)$ for $3 \mathrm{~h}$, slowly rumen degraded, rumen undegraded and indigestible N, Licitra et al., (1996)

PIN: Insoluble $\mathrm{N}$ upon treatment with commercial protease (Streptomyces griseus), Rumen undegraded N, Krishnamoorthy et al., (1995); Licitra et al., (1998)

Knowledge on various $\mathrm{N}$ fractions in feedstuffs including nature and extent of degradability is necessary to understand the protein kinetics and fate in rumen and in order to apply new protein systems in practical ration formulation.

GNC contains $2.74 \%$ ADIN, 39.55\% BIN, $24.97 \%$ PIN and $75.03 \%$ RDN. Corresponding values for guar korma are 2.06, 68.23, 30.87 and 69.13\%; for cotton seed cake are 8.14, 73.23, 51.7 and $48.3 \%$; for soyabean meal are $4.58,55.48,31.73$ and $68.27 \%$, respectively (Mahesh et al., 2017). 


\section{Rumen fermentation studies}

El-Monayer et al., (2015) conducted trial on lactating buffaloes and replaced CSC and soyabean meal protein (ration A) to $10 \%$ (ration B), 20\% (ration C), 30\% (ration D), $40 \%$ (ration $\mathrm{E}$ ) and $50 \%$ (ration $\mathrm{F}$ ) by guar korma protein. They founded that average $\mathrm{pH}$ values gradually increase with increasing guar korma level in experimental rations during different sampling periods with no significantly different. However, $\mathrm{pH}$ values decreased at $3 \mathrm{hrs}$ post feeding and increased again at $6 \mathrm{hrs}$ after feeding. It could be noticed that, effect of sampling time on rumen $\mathrm{pH}$ values showed decreased at $3 \mathrm{hrs}$, then returned to increase at $6 \mathrm{hrs}$ after feeding. This might be related to the fermentation processes of both non-structural and structural carbohydrates to obtain the volatile fatty acids which increased with proceeding time and cause a reduction in ruminal $\mathrm{pH} . \mathrm{NH}_{3}-\mathrm{N}$ concentration with animals fed rations $\mathrm{E}$ and F were significantly $(\mathrm{P}<0.05)$ higher than those fed other rations at 3 and $6 \mathrm{hrs}$ after feeding. This may be due to the greater portion of guar korma in ration $\mathrm{E}$ and $\mathrm{F}$ as a source of protein, which is more degradable in the rumen as reported by Chibisa et al., (2012) and Benchaar et al., (2013). Overall mean of $\mathrm{NH}_{3}-\mathrm{N}$ concentration appeared the same significant $(\mathrm{P}<0.05)$ trend during 3 and $6 \mathrm{hrs}$ after feeding, recording the highest concentration $(20.27 \mathrm{mg} / 100 \mathrm{ml})$ with animals fed ration $\mathrm{F}$ (containing $16.7 \%$ guar korma). With respect to ruminal total VFAs concentration, the significant $(\mathrm{P}<0.05)$ differences were found with increasing guar korma level from 10 to $17.7 \%$ in tested rations, during different sampling times. Concentration of total VFAs gradually increased with increasing guar korma level in rations and at post feeding. Total-N and protein-N concentrations showed significantly $(\mathrm{P}<0.05)$ higher with animals fed rations $\mathrm{E}$ and $\mathrm{F}$, recording increased concentrations with increasing sampling times. Overall average of total-N ranged between 118.82 to $131.29 \mathrm{mg} / 100 \mathrm{ml}$ versus 89.22 to $94.35 \mathrm{mg}$ $/ 100 \mathrm{ml}$ for protein-N concentration, showing the highest concentration was recorded with animals fed ration $F$.

Soliman et al., (2014) replaced soyabean meal $\left(\mathrm{R}_{1}\right)$ by guar korma meal in the ration of female sheep at the rate of $33 \%\left(\mathrm{R}_{2}\right), 66 \%$ $\left(\mathrm{R}_{3}\right)$ and $100 \%\left(\mathrm{R}_{4}\right)$ level The results of ruminal parameters showed insignificant differences $(\mathrm{P}<0.05)$ among experimental animals in the values of ruminal $\mathrm{pH}$ and $\mathrm{NH}_{3}-$ $\mathrm{N}$ concentration. However, the animals fed rations containing guar korma recorded slightly higher $\mathrm{NH}_{3}-\mathrm{N}$ concentration compared with the control animals. On the other hand, the control ration and $\mathrm{R}_{3}$ recorded $(\mathrm{P}<0.05)$ higher total VFAs concentration compared with $\mathrm{R}_{2}$ and $\mathrm{R}_{4}$. This improvement in TVFAs may be due to the increasing of digestibility of organic matter Kholif et al., (2005), El-Ashry et al., (2003). Generally, the level of ammonia and TVFAs concentrations were adequate enough to allow maximum microbial protein synthesis according to McCarthy et al., (1989). There was a linear increase $(\mathrm{P}<0.05)$ in acetic acid percentage and acetic/propionic acid ratio as the level of guar korma meal increased in the rations. Higher $(\mathrm{P}<0.05)$ effective degradability was recorded with ration containing $15 \%$ guar korma, followed by rations contained $10 \%$ and 5\% guar korma. However, the control ration had a significantly lower $(\mathrm{P}<0.05)$ effective degradability of DM.

In a study conducted by Grewal et al., (2014) the concentration of acetic, propionic and butyric acid in SRL of animals fed roasted guar korma and GNC do not vary significantly. But, TVFAs and A:P ratio was statistically higher in roasted guar korma fed group than GNC fed group. Goswami et al., (2012) conducted in-vitro study, by replacing 
GNC in total mixed ration by guar meal at 0 , 25, 50, 75 and 100\% level. He observed decrease in $\mathrm{NH}_{3}$, TCA-ppt. $\mathrm{N}$ and microbial biomass production as level of guar meal increased in total mixed ration. But, TVFAs increased, only at 25 and $50 \%$ replacement level.

In conclusion, the guar korma contains more crude protein as compared to groundnut cake. By replacing 50 or $100 \%$ crude protein of groundnut cake with roasted guar korma in the concentrate mixture of buffalo calves do not affect daily dry matter intake and dry matter intake per $100 \mathrm{~kg}$ body weight revealing good palatability. Feed conversion rate and feed conversion efficiency improves on feeding roasted guar korma as protein source instead of groundnut cake.

\section{References}

Ahmed, M.B., Hamid, R.A., Ali, M.E. and Hassan, A.B. 2006. Proximate composition, antinutritional factors and protein fractions of guar gum seeds as influenced by processing treatments. Pakistan J. Nutr., 5(5): 481-484.

APEDA 2011. Agricultural and Processed Food Products Exports Development Authority. Ministry of Commerce and Industry, Government of India, Benagluru.

Benchaar, C., Hassanat, F., Gervais, R., Chouinard, P.Y., Julien, C., Petit, H.V. and Masse, D.I. 2013. Effect of increasing amounts of corn dried distellers grains with soluble in dairy cow's diets on methane production, ruminal fermentation digestion, $\mathrm{N}$ balance and milk production. J. Dairy Sci., 96: 2413-2427.

Chaturvedi, O.H. and Walli, T.K. 1995. Ruminal OM and protein degradability of some concentrate ingredients using nylon bag technique.
Indian j. Anim. Nutr., 12: 133-139.

Chibisa, G.E., Christensen, D.A. and Mutsvangwa, T. 2012. Effect of replacing canola meal as the major protein source with wheat dried distillers grains with soluble on ruminal function, microbial protein synthesis, omasal flow and milk production in cows. J. Dairy Sci., 95 (2): 824-41.

Conrad, B.E., Neal, E.M. and Riggs, J.K. 1967. Guar meal for beef cattle. J. Anim. Sci., 26: 219.

Couch, J.R., Bakshi, Y.K., Ferguson, T.M., Smith, E.B. and Creger, C.R. 1967. The effect of processing on the nutritional value of guar meal for broiler chicks. British Poult. Sci., 8(4): 243-250.

EI-Ashry, M.A., Kholif, A.M., Fadel, M., ELAlamy, H.M., EL-Sayed, S.M. and Kholif, S.M. 2003. Effect of biological treatments on chemical composition and in vivo digestibilities of poor quality roughages. Egyptian J. Nutr. and Feed, 6: 113-126.

El-Monayer, T.I., Etman, K.E.I., AbouEnin, E.I.I. and El-Sayed, F.A. 2015. Using new protein sources in feeding ruminants. 2- Using guar korma meal in rations of lactating buffaloes. J. Animal and Poultry Prod., 6(8): 537-554.

Etman, K.E.I., AbouEnin, E.I.I., El-Monayer, T.I. and El-Sayed, F.A. 2014. Using new protein sources in feeding ruminants. 1- Effect of feeding different levels of guar korma as a source of protein on the productive performance of Egyptian buffaloes. J. Animal and Poultry Prod., 5(12): 619-634.

Goswami, A., Thakur, S.S. and Amrutkar, S.A. 2012. Growth and nutrient utilization in calves fed guar (Cyamopsis tetragonoloba) meal replacing ground nut cake in concentrate with and without added sweetner and flavour. Indian j. Anim. Nutr., 29 (1): 40-45. 
Grewal, R.S., Lamba, J.S., Ahuja, C.S., Amanpeet Kaur and Saijpaul, S. 2014. Evaluation of guar by-products as replacement of soyabean meal in buffaloes. Indian J. Anim. Nutr., 31(2): 119-123.

Gutierrez, O., Zhang, C., Cartwright, A.L., Carey, J.B. and Bailey, C.A. 2007. Use of guar byproducts in high-production laying hen diets. Poult. Sci.,86: 11151120.

Hassan, S.M., Al-Yousef, Y.M. and Bailey, C.A. 2013. Effects of guar bean, guar meal and guar gum on productive performance of broiler chicks. Asian J. Poult. Sci., 7(1): 34-40.

Hassan, S.M., Haq, A.U., Byrd, J.A., Berhow, M.A., Cartwright, A.L. and Bailey, C.A. 2010. Haemolytic and antimicrobial activities of saponin-rich extracts from guar meal. Food Chem., 119: 600-605.

Islam Shah, S.S., Sial, M.B. and Schneider, B.H. 1964. The nutritive value of guar meal. J. Anim. Sci., 23: 892 (Abstract).

Janampet. RK., Kumar, M., Rajanna, N., Satyanarayana, C.S. and Raghunandan, T. 2016. Effect of feeding guar meal on nutrient utilization and growth performance in Mahbubnagar local kids. Vet. World, 9(10): 1043-1046.

Jongwe, C., Thakur, S.S., Kaur, J. and Mahesh, M.S. 2014. Effect ofreplacing Ground nut cake with Guar (Cyamopsis tetragonoloba) meal in concentrate mixture with and without added sweetner and flavour on production performance of Sahiwal cows. Indian j. Anim. Nutr., 31 (2): 138-142.

Kawatra, B.L., Garcha, J.S. and Wagle, D.S. 1969. Studies on guar (Cyamopsis tetragonoloba) protein. Indian J. Nutr. Dietet., 6: 91.

Kholif, A.M., El-Alamy, H.A., El-Sayed, H.M., El-Ashry, M.A. and Kholif, S.M. 2005. Biological treatments of banana wastes for lactation cows feeding.
Egyptian J. Nutrition and Feeds, 4: 433438.

Krishnamoorthy, U., Soller, H., Steingass, H. and Menke, K.H. 1995. Energy and protein evaluation of tropical feedstuffs for whole tract and ruminal digestion by chemical analyses and rumen inoculum studies in vitro. Anim. Feed Sci. Technol., 52: 177-188.

Lee, J.T., Bailey, C.A. and Cartwright, A.L. 2009. In vitro viscosity as a function of guar meal and beta-mannanase content of feeds. Int. J. Poult. Sci., 8 (8): 715719.

Lee. J., Connor-Appleton, A., Bailey, H.C. and Cartwright, A. 2004. Quantitative measurement of negligible trypsin inhibitor activity and nutrient analysis of guar meal fractions. J. Agric. Food Chem., 52: 6492-6495.

Licitra, G., Hernandez, T.M. and Van Soest, P.J. 1996. Standardisation of procedures for nitrogen fractionation of ruminant feeds. Anim. Feed Sci. Technol., 57: 347-358.

Licitra, G., Van Soest, P.J., Schadt, I., Carpinoc, S. and Sniffen, C.J. 1998. Influence of the concentration of the protease from Streptomyces griseus relative to ruminal protein degradability. Anim. Feed Sci. Technol., 77: 99-113.

Mahesh, M.S., Thakur, S.S., Kumar, R., Malik, T.A. and Gami, R. 2017. Nitrogen fractionation of certain conventional- and lesser-known byproducts for ruminants. Animal Nutrition, 3: 186-190.

Mandal, A.B., Aggarwal, S.P., Khirwar, S.S. and Vidyasagar. 1989. Effect of clusterbean meal (Cyamopsis tetragonoloba) on nutrient utilization and thyroid hormones in buffalo calves. Indian J. Anim. Nutr., 6: 187-193.

McCarthy, R.D., Klusmeyer, T.H., Vicini, J.L., Clark, J.H. and Nelson, D.R. 1989. 
Effects of source of protein and carbohydrate on ruminal fermentation and passage of nutrients to the small intestine of lactating cows. J. Dairy Sci.,72: 2002-2016.

Michalet-Doreau, B. and Ould-Bah, M.Y. 1993. In vitro and in sacco methods for the estimation of dietary nitrogen degradability in rumen: A review. Animal Feed Science and Technology, 40: 57-86.

Mishra, A., Sarkar, S.K., Ray, S. and Haldar, S. 2013. Effects of partial replacement of soybean meal with roasted guar korma and supplementation of mannanase on performance and carcass traits of commercial broiler chickens. Vet. World, 6(9): 693-697.

Nelson, L. 1965. Personal correspondence. Lawn elson Corp., New York, [N.Y.of Holstein dairy cows. J. Anim. Sci. Vol. 88, E-Suppl. 2/J. Dairy Sci. Vol. 93, ESuppl. 1/Poult. Sci. Vol. 89, E-Suppl. 1 Publ. Beeville, Texas.

Nidhina, N. and Muthukumar, S.P. 2015. Antinutritional factors and functionality of protein-rich fractions of industrial guar meal as affected by heat processing. Food Chem., 173: 920-926.

Nocek, J.E. 1988. In situ and other methods to estimate ruminal protein and energy digestibility: A review. J. Dairy Sci.,71: 2051-2069.

Orskov, E.R. and McDonald, I. 1979. The estimation of protein degradability in the rumen from incubation measurements weighed according to rate of passage. Journal of Agricultural Sciences, 92: 499-505.

Rahman, M.S. and Leighton, R.E. 1968. Guar meal in dairy rations. J. Dairy Sci., 51(10): 1667- 1671

Rajput, L.P., Ramamani, S., Haleem, M.A. and Subramanian, N. 1998. Chemical and biological studies on processed Guar (Cyamopsis tetragonoloba) meal.
Indian J. Poult. Sci., 33(1): 15-25.

Sadagopan, V.R. and Talapatra, S.K. 1967. Biological assay of guar-meal (Cyamopsis psoraloides) on growth rate of Hariana calves. Indian Vet. J., 44: 1061.

Sadagopan, V.R. and Talapatra, S.K. 1968. Biological assay of guar-meal (Cyamopsis psoraloides) on growth rate of Haryana calves. Indian Vet. J., 45: 241.

Saeed, M., Hassan, F., Shah, Q.A., Arain, M.A., Abd El-Hack, M.E., Alagawany, M. and Dhama. K. 2017. Practical Application of Guar (Cyamopsis tetragonoloba L. Taub) Mealin Poultry Nutrition. Advances in Animal and Veterinary Sciences, 5 (12): 491-499.

Sagar, V. and Pradhan, K. 1975. Feeding of guar meal as a sole concentrate and its effect on nutrient intake and growth of calves. Indian J. Dairy Sci., 28: 89.

Sagar, V. and Pradhan, K. 1977. Effect of replacing groundnut-cake with clusterbean-meal on feed intake and growth of growing crossbred calves. Indian J. Anim. Sci., 47: 313-317.

Sharif, M., Nazar, M., Sultan, J.I., BilaL, M.Q., Shahid, M. and Hussain, A. 2014. Effect of replacing cotton seed cake with guar meal on growth performance and economics in sahiwal calves. The Journal of Animal and Plant Sciences, 24: 28-32.

Sharma, P. and Gummagolmath, K.C. 2012. Reforming guar industry in India: Issues and strategies. Agricultural Economics Research Review, 25(1): 37-48.

Sniffen, C.J., O'Connor, J.D., VanSoest, P.J., Fox, D.G. and Russel, J.B. 1992. A net carbohydrate and protein system for evaluating cattle diets II. J. Anim. Sci., 70: 3562-3577.

Soliman, M.S., A. M.El- Okazy and Salma H. Abu Hafsa 2014. Effect of partially or totally replacing soybean meal by guar 
korma meal on sheep and cow's performance milk production. Animal and Poultry Prod., 5(2): 43-55.

Soliman, M.S., A. M.El- Okazy and Salma H. Abu Hafsa 2014. Effect of partially or totally replacing soybean meal by guar korma meal on sheep and cow's performance milk production. Animal and Poultry Prod., 5(2): 43-55.

Srivastva, S.P. and Singh, G.S. 1960. Digestibility coefficients and nutritive value of guarmeal or chuni. Indian $J$. Dairy Sci., 13: 136.

Stern, M.D., Bach, A. and Calsamiglia, S. 1997. Alternative techniques for measuring nutrient digestion in ruminants. J. Anim. Sci., 75: 2256-2276.

Subramanian, N. and Parpia, H.A.B. 1975. Processing of Guar to obtain high grade protein concentrate. In PAG Compedium Vol. D., World Mark Press, New York, p. 2015.

Tasneem, R. and Subramanian. 1990. Nutritional quality of aqueous alcohol extracted guar (Cyamopsis tetragonoloba) meals. J. Agric. Food.
Chem., 34: 853.

Tyagi, P.K., Mandal, A.B. and Tyagi, P.K. 2011. Utilization of roasted guar (Cyamopsis tetragonoloba) korma in the diet of broiler chickens. Indian J. Poult. Sci., 46(3): 326-329.

Verma, S.V.S. and McNab, J.M. 1982. Guar meal in diets for broiler chickens. Brit. Poult. Sci., 23(2): 95-105.

Vishwakarma, R.K., Shivhare, U.S. \& Nanda, S.K. 2012. Physical Properties of Guar Seeds. Food and Bioprocess Technology, 5(4): 1364-1371.

Walaa, M., Salah, K., Reda A.M., Mohamed S. and Hassan M. 2016. Effect of using guar korma meal as a new source of protein on productive performance of buffalos. Asian j. Anim. Sci., 10.3923: 300-306.

Walli, T.K., Das, M.M., Rai, S.N. and Garg, M.R. 2000. Effect of heat treatment on protein degradability, $\mathrm{N}$ solubility and ammonia release of groundnut cake and soybean meal. Indian Journal of Dairy Science, 53: 361-368.

\section{How to cite this article:}

Mohit Antil and Sandeep Chhikara. 2019. Guar Korma: A Good Alternate to Replace Groundnut Cake in the Diet of Buffalo Calves: A Review. Int.J.Curr.Microbiol.App.Sci. 8(02): 1805-1816. doi: https://doi.org/10.20546/ijcmas.2019.802.212 